\title{
Statistical evaluation of tablet coating processes: influence of pan design and solvent type
}

\author{
Valdomero Pereira de Melo Junior ${ }^{1, *}$, Raimar Löbenberg², Nádia Araci Bou-Chacra1 \\ ${ }^{1}$ Faculty of Pharmaceutical Sciences, Department of Pharmacy, University of São Paulo, ${ }^{2}$ Faculty of Pharmacy and \\ Pharmaceutical Sciences, University of Alberta, Edmonton, Canada
}

\begin{abstract}
Partially and fully perforated pan coaters are among the most relevant types of equipment currently used in the process of coating tablets. The goal of this study was to assess the performance differences among these types of equipment employing a factorial design. This statistical approach allowed the simultaneous study of the process variables and verification of interactions among them. The study included partially-perforated and fully-perforated pan coaters, aqueous and organic solvents, as well as hypromellose-based immediate-release coating. The dependent variables were process time, energy consumption, mean weight of tablets and process yield. For the tests, placebo tablets with a mean weight of $250 \mathrm{mg}$ were produced, divided into eight lots of two kilograms each and coated in duplicate, using both partially perforated pan and fully perforated pan coaters. The results showed a significant difference between the type of equipment used (partially and fully perforated pan coaters) with regard to process time and energy consumption, whereas no significant difference was identified for mean weight of the coated tablets and process yield.
\end{abstract}

Uniterms: Tablets/coating process. Fully perforated pan coater. Partially perforated pan coater.

\begin{abstract}
Entre os tipos de equipamentos de maior relevância utilizados atualmente no processo de revestimento de comprimidos estão os de tambor parcial e totalmente perfurados. A proposta desse trabalho foi avaliar as diferenças de desempenho entre esses equipamentos empregando projeto fatorial. Essa abordagem estatística possibilitou o estudo simultâneo das variáveis do processo, permitindo verificar interações entre elas. $\mathrm{O}$ trabalho incluiu equipamento com tambor parcialmente perfurado e totalmente perfurado, solventes aquoso e orgânico, assim como revestimento de liberação imediata à base de hipromelose. As variáveis dependentes ou respostas foram tempo de processo, consumo de energia, peso médio e rendimento do processo. Para os ensaios, foram produzidos comprimidos de placebo de $250 \mathrm{mg}$ de peso médio, divididos em 8 lotes de dois quilogramas cada e revestidos em duplicata, tanto no equipamento com tambor parcialmente perfurado quanto no equipamento de tambor totalmente perfurado, obedecendo a matriz de ensaio previamente definida. Os resultados mostraram que existe diferença significativa entre equipamento de tambor parcialmente perfurado e totalmente perfurado, para tempo de processo e consumo de energia. Já para peso médio dos comprimidos revestidos e rendimento do processo, os dois equipamentos não apresentaram diferença significativa.
\end{abstract}

Unitermos: Comprimidos/processo de revestimento. Revestidora com tambor totalmente perfurado. Revestidora com tambor parcialmente perfurado.

\section{INTRODUCTION}

Over the past 60 years, the coating process of solid oral pharmaceutical dosage forms has developed significan-

\footnotetext{
*Correspondence: V. P. Melo. Departamento de Farmácia, Faculdade de Ciências Farmacêuticas, Universidade de São Paulo. Av. Prof. Lineu Prestes, 580 - Cidade Universitária - 05508-000 - São Paulo - SP, Brazil. E-mail: valdomero@usp.br
}

tly, consolidating in the 1970s and 1980s with the gradual substitution of the conventional sugar coating by polymeric film. In the 1960s, several polymers were developed aiming at different applications, when it was believed that tablets should not be exposed to conditions considered potentially compromising to tablet quality, such as excessive heat or moisture. Both are intrinsic conditions of aqueous coating processes using polymeric film (Avis, Shukla, Chang, 1998). 
The types of equipment used for tablet coating evolved in parallel with the development of new polymeric materials. Equipment featuring conventional or non-perforated pans, as used in sugar coating, were gradually substituted by equipment featuring partially or fully perforated pans to improve the efficiency of the tablet coating process. These types of equipment currently feature different degrees of integrated automation, which allows each process parameter to be monitored and controlled, as well as continually recorded. These measures assure an elevated degree of consistency in the coating process, which is an essential characteristic for validated processes (Bauer et al., 1998).

The acquisition of new technology requires broad technical and scientific knowledge about the processes performed and the analysis of all available information concerning the equipment and process. Generally, this information can be obtained from the equipment manufacturer. In the case of pharmaceutical manufacturers, any equipment substitution must also consider regulatory aspects. Any new machinery may lead to regulatory agencies requiring new stability tests for the product, which may result in an interruption of product availability while the tests are being carried out.

According to SUPAC (Scale up and post-approval changes guideline), published by the FDA in 1999 concerning immediate- and modified-release oral solid pharmaceutical dosage forms, tablet-coating equipment featuring pans are classified into two categories: conventional or nonperforated pan coaters, and perforated pan coaters (FDA, 1999). This latter type of equipment includes equipment featuring fully and partially perforated pans. The FDA does not differentiate between these types of equipment.

The current literature lacks studies which can guide scientists and management on the decision to acquire either fully or partially perforated pan coating equipment. However, this information is paramount when it comes to process optimization or in cases of technology transfer to adjust and optimize process parameters between equipment types.

Furthermore, questions concerning energy consumption in the production processes are becoming increasingly more relevant. Due to increasing energy costs, the process efficiency becomes a driving force toward competitiveness in a global market. In this sense, organizations such as the International Energy Initiative have added the need of rational use of energy to manufacturing (IEI, 2008). Thus, comparative process analysis should include, besides technical questions, an assessment of energy consumption.

Given that regulatory agencies such as the FDA currently have no guidelines to address differences in process efficiency between coating equipment, while scant information is available from equipment manufacturers, this study examined differences between fully and partially perforated pan coaters.

The methodology of Design of Experiment (DOE) ensures that all factors and their interactions are systematically investigated, thus, information obtained from a DOE analysis is much more reliable and complete than results from one-factor-at-a time experiments that ignore interactions and may lead to misleading conclusions (Montgomery, 2004). DOE has been used to improve the understanding of the relationship between product and process parameters and the desired performance characteristics such as in the coating process (Porter, Verseput, Cunningham, 1997). By this approach, the comparison between a laboratory and a production coating spray gun with respect to scale up was determined using a statistical model and surface plots. The study revealed that spray guns are highly comparable with respect to droplet size and velocity (Mueller, Kleinebudde, 2007). Additionally, the identification of critical process variables for coating actives onto tablets was performed via statistically designed experiments. The atomization pressure was identified as a major variable with respect to content uniformity (Rege, Gawel, Kou, 2002).

\section{MATERIAL AND METHODS}

\section{Material}

The raw material used for preparing the tablets were: Microcrystalline cellulose (Ipiranga Química, São Paulo, Brazil), Lactose (Selectchemie, São Paulo, Brazil), Copolividone (ISP, São Paulo, Brazil), Crospovidone (ISP, São Paulo, Brazil), Silicon dioxide (Degussa, São Paulo, Brazil), Stearic acid (Ipiranga Química, São Paulo, Brazil).

The material used for preparing the coating dispersions were: Hypromellose (Shinetsu, São Paulo, Brazil), Polyethylene glycol 400 (Clariant, São Paulo, Brazil), Titanium dioxide (Sensient, São Paulo, Brazil), FD\&C Blue No. 1 aluminum lake (Sensient, São Paulo, Brazil), FD\&C** Yellow No. 10 aluminum lake (Sensient, São Paulo, Brazil).

The equipment used in the tests were: Mettler-Tole$\mathrm{do}^{\circledR}$ analytical digital scales, model AB204-S (Mettler, São Paulo, Brazil), Amard ${ }^{\circledR}$ V-shaped mixer, 13 liters (Amard, São Paulo, Brazil), Riva ${ }^{\circledR}$ Tablet machine, model Piccola ${ }^{\circledR}$, 8-station (Riva, Buenos Aires, Argentina), helical mixer IKA RW20.n (IKA, São Paulo, Brazil), Ultra-Turrax T25 disperser (IKA, São Paulo, Brazil), Hi-Coater LDCS-5 Vector equipment (AMI, Paulínia, Brazil), with fully perforated 6-liter pan, or with partially perforated 6-liter pan (the same equipment was used in all tests; only the pan was 
changed since this model is compatible with both types used in the study), Datacolor ${ }^{\circledR} 600$ spectrophotometer (Color Z, Osasco, Brazil), Kron digital transducer, model Multi-K 120 (Cybra, São Paulo, Brazil).

\section{Statistical planning}

A $2^{2}$ factorial design was used to assess the influence of the categorical variables (type of solvent and type of equipment) on the tablet coating. Duplicates of each experiment were done generating a total of eight product lots, obtained according to the experimental conditions outlined in Table I.

The chronological order to perform the analysis followed a random order since alternatives may lead to biased results. The random order is presented in Table I.

TABLE I - Factorial design of assays considering two variables: equipment and type of solvent

\begin{tabular}{ccc}
\hline Lots (random order) & Equipment & Solvent \\
\hline 1 & partially perforated & organic \\
2 & partially perforated & organic \\
3 & partially perforated & aqueous \\
4 & perforated & organic \\
5 & perforated & organic \\
6 & partially perforated & aqueous \\
7 & perforated & aqueous \\
8 & perforated & aqueous \\
\hline
\end{tabular}

\section{Preparation of tablets and compression sampling}

Initially, all excipients, except for stearic acid, were transferred to a 13-liter V-shaped mixer. The excipients were mixed for 20 minutes at $20 \mathrm{rpm}$. After this period, magnesium stearate was added and the mixing was carried out for an additional 5 minutes. After mixing the powder was compressed using biconcave punches $(9 \mathrm{~mm})$. The tablet target weight was $250 \mathrm{mg}$ with a hardness of 8 to $14 \mathrm{kP}$, tablet friability had to be lower than $0.2 \%(\mathrm{w} / \mathrm{w})$ and the disintegration time shorter than 300 seconds. Every 15 minutes, 200 tablets were taken to perform physical tests.

\section{Assessment of tablets}

The values of individual and mean weight, hardness, disintegration time and friability were determined according to the United States Pharmacopeia (2008).

The results obtained by the tests were evaluated for process stability and normal distribution of the data.
This was done in accordance with a protocol published by Vissotto et al. (2007, 2008). In addition, this study determined the process capability indices (Vissotto et al., 2008). These assessments aimed to investigate if the compression process was sufficiently stable to produce tablets with acceptable variations for the coating process. These evaluations were performed using Minitab ${ }^{\circledR}$ Ver. 15 (Minitab Brasil, Belo Horizonte, Brazil).

\section{Coating}

The coating dispersion was prepared by adding hypromelose and macrogol 400 to one part solvent, either water or $90 \%$ ethanol. An IKA RW20.n helical mixer was used to stir the solution. Pigments titanium dioxide, FD\&C blue No. 1 aluminum lake and FD\&C yellow No. 10 aluminum lake, were dispersed in parts of the solvent using an Ultra-Turrax T25 for five minutes. The pigment dispersion was then transferred to the dispersion containing hypromellose and macrogol 400 and kept under stirring for an additional period of 30 minutes.

The tablets were coated with the coating dispersion previously prepared in a Vector ${ }^{\circledast}$ LDCS-5 equipment, with a 6-liter pan, using a two-component spray gun with an exit orifice of $0.7 \mathrm{~mm}$, the distance from the tablets was 12 centimeters for aqueous coating, and 10 centimeters for organic coating, the atomization pressure was between 1,500 and 1,600 mbar and pan rotation speed was between 10 and $12 \mathrm{rpm}$. The product temperature was between $39^{\circ} \mathrm{C}$ to $44{ }^{\circ} \mathrm{C}$ for aqueous coatings and $35^{\circ} \mathrm{C}$ to $40{ }^{\circ} \mathrm{C}$ for organic coatings. The same equipment was used with the partially and fully perforated pans. The processing conditions were established for each lot to obtain a coated tablet with a good final finish: a) no defects such as roughness, visible spots; b) uniform colour over the whole surface. The time needed to meet these criteria was recorded. Previously successfully used values for the inlet temperature entering the pan, the air flow and application rate were selected for the coating of each lot.

\section{Assessment of the coated tablets}

In accordance with the United States Pharmacopeia (2008), the mean weight and individual weight were determined using 100 units of each of the eight lots of coated tablets (Pearn, Lin, 2004).

The determination of the disintegration time was performed for the coated tablets, using an Erweka ${ }^{\circledR}$ model ZT-502, water at $37^{\circ} \mathrm{C}$ as the immersion medium, and the methodology described by the United States Pharmacopeia (2008). 


\section{Assessment of critical process parameters}

The energy consumption was determined in all tests, employing a digital Multi-K $120 \mathrm{Kron}^{\circledR}$ transducer coupled to the LDCS-5 Vector coating equipment and an Acer computer model Aspire 5100. These values were collected at intervals of 10 minutes.

The evaluation of the coating uniformity was based on the methods proposed by Alcorn et al. (1988) and Smith et al. (2003). The values of DL, Da, Db were used for the evaluation of colour uniformity of the coated tablet among the different lots. Ten tablets from each lot were sampled and a colour reading was carried out. The mean values of $\mathrm{L} * \mathrm{a} * \mathrm{~b} *$ were used to calculate $\Delta \mathrm{E}$ between the lots.

Colour differences, represented by $\Delta \mathrm{E}$, were calculated through the equation (1) below:

$$
\Delta \mathrm{E}=\left[\left(\Delta \mathrm{L}^{*}\right)^{2}+\left(\Delta \mathrm{a}^{*}\right)^{2}+\left(\Delta \mathrm{b}^{*}\right)^{2}\right]^{1 / 2}
$$

Tolerances for $\Delta \mathrm{E}$ usually vary between one and two units of $\Delta \mathrm{E}$ (McDonald, 1997). This is due to the human eye which is able to detect colour variations corresponding to $\Delta \mathrm{E}>1.5$ (Chan, Chan, Heng, 2001).

Samples from each lot were evaluated using a Datacolor $^{\circledast} 600$ spectrophotometer set for the following parameters: $6.3 \mathrm{~mm}$ slot, 3 shots, ultraviolet potential equal to zero, D65 Deg light source (simulation of natural daylight, according to MacDonald, 1997) and brightness of specular highlight.

The process yield was calculated employing the equation (2) below:

Theoretical yield $=\frac{\text { Final actual mean weight } \mathrm{x} 100}{\text { Final theoretical mean weight }}$

\section{RESULTS AND DISCUSSION}

\section{Assessment of tablet core manufacturing process stability}

The control and the moving range charts for individual weights and hardness showed that the processes were under statistical control (only occurrences that contribute to natural variation were observed) (data not shown).

The Anderson-Darling statistics showed that the data followed a normal distribution, with a p-value of 0.05 and 0.23 , for individual weight and hardness, respectively.

Concerning the capability analysis, the index for individual weight (1.75) estimated the absence in one million cores (1 ppm) below the specific limit (ppm $<$ LSL) and the probability of 8 cores above the specific limit in
100 million cores (100 ppm > USL). For tablet hardness, the capability index was 1.26 with an estimated probability of 34 out of 1 million tablets below and a probability of 82 cores above the specific limits.

These probabilities indicate the consistency of the process and, therefore, similar to the previous analysis, the process was capable of producing tablets which meet the pre-established specifications.

The placebo tablets produced showed acceptable variability and proved adequate for the coating process.

This is in accordance with studies by Han (2006), Heuvel, Ion (2003) and Lin, Sheen (2005). These authors showed that control charts, statistical analysis of normal distribution as well as capability analysis were adequate tools for evaluating process variability.

\section{Assessment of colour uniformity in coating process}

Table II shows values of $\mathrm{L}, \mathrm{a}$, and $\mathrm{b}$ for the last sample of each lot of coated tablets and values of $\Delta \mathrm{E}$ between the two similar coated batches (lots 1 to 8 ). The values obtained were close to 2 , thus indicating a slight colour variation between the lots. This colour variation detected by the equipment could not be visually verified.

Similarly, Chan et al. (2001) and Smith et al. (2003) showed that the colour test employed is an adequate tool for evaluating process uniformity.

\section{Process time}

The statistical analysis of the process times (Table III) showed that the coefficients for the solvent and the equipment variables (14.375 and -6.875) were all significant (p-value of 0.001 and 0.010 , respectively for the solvent and the equipment, at an $\alpha$-level of 0.05 ) and no interactions between these factors were observed $(\mathrm{p}=0.494)$.

The main effects (solvent and equipment) for the process time response revealed a shorter process time for the combination of aqueous solvent with partially perforated pan coating equipment. A combination of organic solvent with fully perforated pan coating equipment showed a longer process time. (Table IV)

\section{Energy consumption}

As predicted, the energy consumption and process time exhibit a direct relationship (the statistical analysis showed p-values equal to zero for both variables: solvent and equipment). 
TABLE II - Values L, a, b in the assay for assessment of colour uniformity in the core coating step, employing partially and fully perforated pan coating equipment, at the end of each assay, and values of $\Delta \mathrm{E}$ between pairs out of the eight lots of coated tablets produced

\begin{tabular}{|c|c|c|c|c|c|c|c|c|c|c|c|c|}
\hline & & \multicolumn{8}{|c|}{ LOTS } & \multicolumn{3}{|c|}{ Values of $L, a, b$} \\
\hline & & 1 & 2 & 3 & 4 & 5 & 6 & 7 & 8 & $\mathbf{L}$ & a & b \\
\hline \multirow{8}{*}{ ְִ } & 1 & - & - & - & - & - & - & - & - & 58.66 & -46.39 & 10.89 \\
\hline & 2 & 0.3 & - & - & - & - & - & - & - & 58.91 & -46.41 & 10.87 \\
\hline & 3 & 1.7 & 1.6 & - & - & - & - & - & - & 59.89 & -47.58 & 10.59 \\
\hline & 4 & 2.5 & 2.4 & 1.6 & - & - & - & - & - & 59.78 & -48.38 & 12.02 \\
\hline & 5 & 0.9 & 0.9 & 1.5 & 1.7 & - & - & - & - & 58.74 & -47.17 & 11.39 \\
\hline & 6 & 2.6 & 2.5 & 1.0 & 1.5 & 2.1 & - & - & - & 60.09 & -48.54 & 10.53 \\
\hline & 7 & 1.5 & 1.5 & 0.9 & 1.7 & 1.1 & 1.3 & - & - & 59.02 & -47.87 & 10.62 \\
\hline & 8 & 2.3 & 2.1 & 0.9 & 0.8 & 1.6 & 1.0 & 1.4 & - & 60.13 & -48.05 & 11.37 \\
\hline
\end{tabular}

$\mathrm{L}=116\left(\mathrm{Y} / \mathrm{Y}_{\mathrm{n}}\right)^{1 / 3}-16$

$\left.\mathrm{a}=500\left[\mathrm{X} / \mathrm{X}_{\mathrm{n}}\right)^{1 / 3}-\left(\mathrm{Y} / \mathrm{Y}_{\mathrm{n}}\right)^{1 / 3}\right]$

$\mathrm{b}=200\left[\left(\mathrm{Y}_{\mathrm{n}} \mathrm{Y}_{\mathrm{n}}\right)^{1 / 3}-\left(\mathrm{Z} / \mathrm{Z}_{\mathrm{n}}\right)^{1 / 3}\right](\mathrm{McDONALD}, 1997)$

TABLE III - Test of significance for regression coefficients and adjustment indices in the model selected in the assay for assessment of uniformity in the core coating employing organic and aqueous solvents and partially and fully perforated pan coating equipment for process time

\begin{tabular}{lccccc}
\hline Terms & Effect & Coef & Coef SE & T & P \\
\hline Constants & & 75.125 & 1.495 & 50.26 & 0.000 \\
Solvent & 28.750 & 14.375 & 1.495 & 9.62 & 0.001 \\
Equipment & -13.750 & -6.875 & 1.495 & -4.60 & 0.010 \\
Solvent x equipment & -2.250 & -1.125 & 1.495 & -0.75 & 0.494 \\
\hline
\end{tabular}

$\mathrm{S}=4,22788$ PRESS $=286$

$\mathrm{R}-\mathrm{Sq}=96.62 \% \mathrm{R}-\mathrm{Sq}(\mathrm{pred})=86.46 \% \mathrm{R}-\mathrm{Sq}(\mathrm{adj})=94.08 \%$

Coef.: coefficients; Coef SE: standard error of coefficients; p: significance level; T: T statistics (T test)- Coef./SE Coef.

Adjustment indices of the model: R-Sq (determination coefficient), R-Sq(adj) (adjusted determination coefficient); R-Sq (pred) (determination coefficient of the adjusted model preview).

TABLE IV - Conditions adopted in the tablet coating step for lots 1 to 8

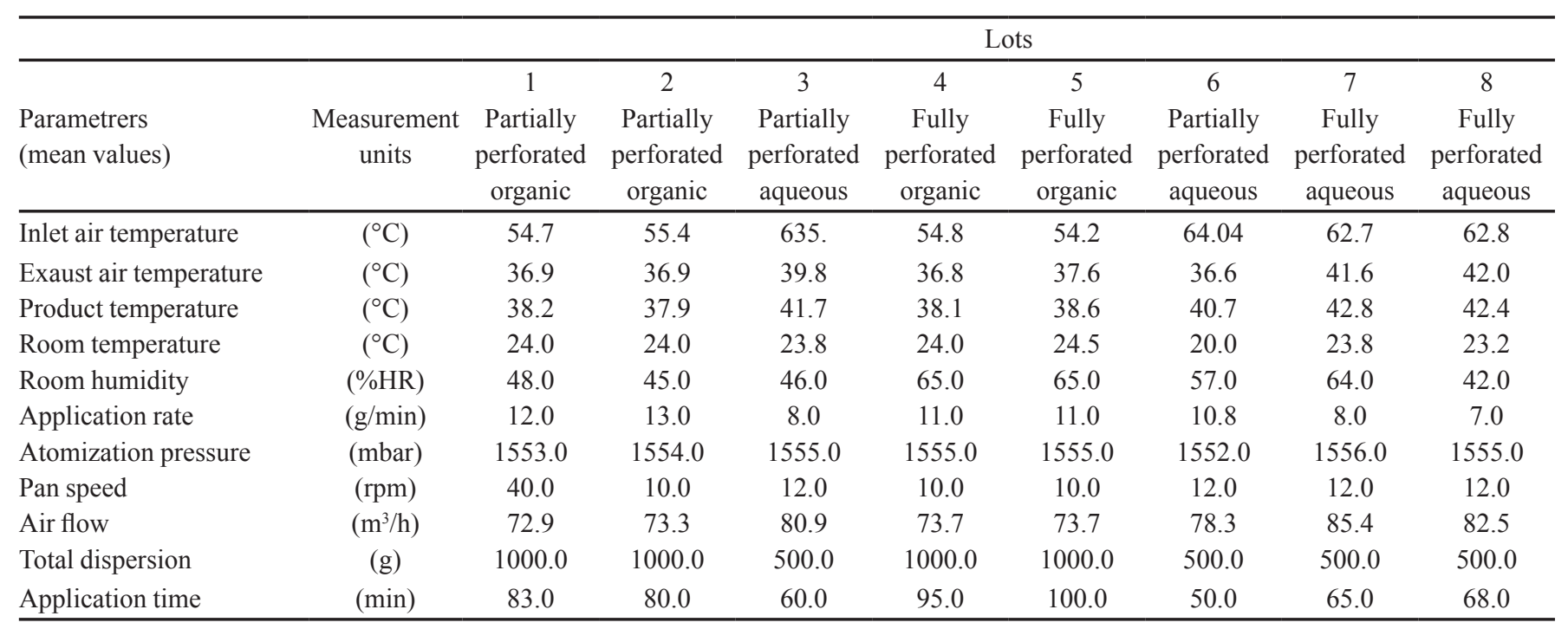


TABLE V - Total energy consumption for lots 1-8 during core coating step

\begin{tabular}{|c|c|c|c|c|c|c|c|c|}
\hline & \multicolumn{8}{|c|}{ Lots } \\
\hline & 1 & 2 & 3 & 4 & 5 & 6 & 7 & 8 \\
\hline Total energy consumption ( $\mathrm{kW}$ ) & 3.213 & 3.135 & 2.756 & 3.824 & 3.869 & 2.760 & 3.163 & 3.300 \\
\hline $\begin{array}{l}\text { Lot } 1 \text { - partially perforated/organic } \\
\text { Lot } 2 \text { - partially perforated/organic } \\
\text { Lot } 3 \text { - partially perforated/aqueous } \\
\text { Lot } 4 \text { - fully perforated/organic }\end{array}$ & & $\begin{array}{l}\text { Lot } 5 \\
\text { Lot } 6 \\
\text { Lot } 7 \\
\text { Lot } 8\end{array}$ & $\begin{array}{l}\text { lly perfo } \\
\text { rtially p } \\
\text { lly perfo } \\
\text { lly perfo }\end{array}$ & $\begin{array}{l}\text { d/orga } \\
\text { rated/a } \\
\text { ed/aque } \\
\text { ed/aque }\end{array}$ & & & & \\
\hline
\end{tabular}

Table V shows the values of total energy consumption, measured in $\mathrm{kW}$, during the tablet coating for all eight lots.

Defining the highest consumption $(3.8465 \mathrm{~kW}$, verified in the fully perforated/organic combination) as $100 \%$ it was possible to calculate the relative decrease in energy consumption observed by other combinations: 16.0, 17.5, $28.3 \%$,for fully perforated/aqueous, partially perforated/ organic and partially perforated/aqueous, respectively. The energy consumption profiles during the tablet coating were similar in all lots (Figure 1). Only process time showed differences between the pair of lots. The longer the process time, the higher the energy consumption.

Information comparing the energy consumption on similar production equipment is not readily available.
However, this data would be helpful for the optimization of processes and to select the most appropriate equipment for each process.

\section{Equipment versus process time versus energy consumption}

The difference in pan design used in the coater might explain the results concerning process time and consequently the energy consumption observed. The air flow in partially perforated pan coating equipment remains directed at the tablet bed during the process, which assures sufficient use of the air entering the pan with a minimum loss of heat.

This is in accordance with the data shown in Table IV, where for the same solvent, the mean application rate

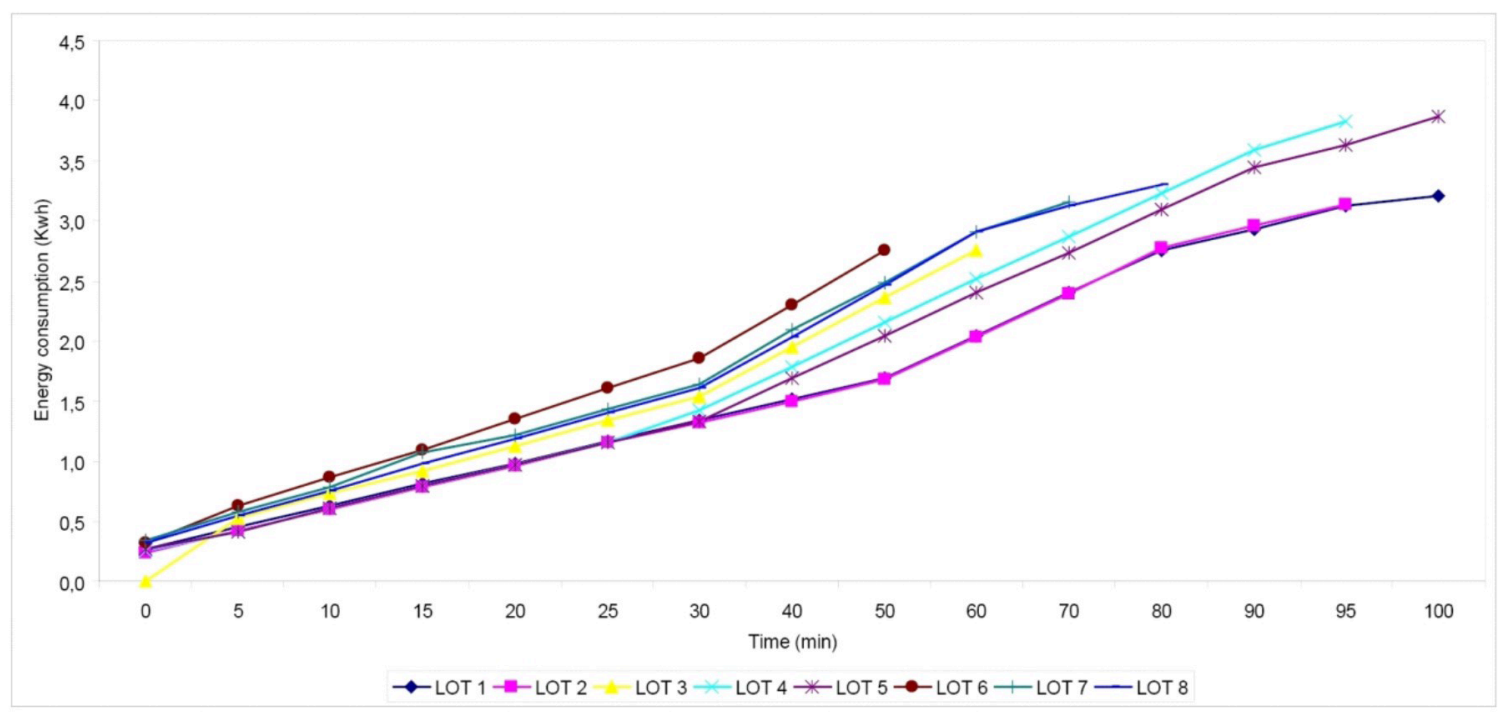

Legend:
Lot 1 - partially perforated/organic
Lot 5 - fully perforated / organic
Lot 2 - partially perforated / organic
Lot 6 - partially perforated / aqueous
Lot 3 - partially perforated /aqueous
Lot 7 - fully perforated / aqueous
Lot 4 - fully perforated/ organic
Lot 8 - fully perforated / aqueous

FIGURE 1 - Energy consumption graph as a function of time for lots 1-8 during core coating step. 
TABLE VI - Mean weight and standard deviation for lots 1-8 of coated tablet cores

\begin{tabular}{lcccccccc}
\hline & \multicolumn{1}{c}{ Lots } & $\mathbf{5}$ & $\mathbf{6}$ & $\mathbf{7}$ & $\mathbf{8}$ \\
\cline { 2 - 9 } & $\mathbf{1}$ & $\mathbf{2}$ & $\mathbf{3}$ & $\mathbf{4}$ & $\mathbf{5}$ & $\mathbf{6}$ & 256.2 \\
Mean weight $(\mathrm{mg})$ & 256.4 & 257.0 & 257.3 & 258.2 & 256.2 & 256.5 & 256.1 & 25.9 \\
Standard deviation & 2.0 & 1.9 & 1.7 & 2.1 & 2.2 & 2.2 & 1.9 & 1.9 \\
\hline
\end{tabular}

TABLE VII - Actual and theoretical mean weight of coated tablet cores and theoretical yield of lots 1 to 8 during core coating step, considering theoretical core weight only

\begin{tabular}{lcccccccc}
\hline & \multicolumn{7}{c}{ Lots } \\
\cline { 2 - 8 } & 1 & 2 & 3 & 4 & 5 & 6 & 7 & 8 \\
\hline Actual mean weight of coated cores (mg) & 256.4 & 257.0 & 257.3 & 258.2 & 256.2 & 256.5 & 256.1 & 256.2 \\
Theoretical mean weight of coated cores (mg) & 257.5 & 257.5 & 257.5 & 257.5 & 257.5 & 257.5 & 257.5 & 257.5 \\
Actual yield (\%) & 99.6 & 99.8 & 100.0 & 100.0 & 99.2 & 99.7 & 98.8 & 99.1 \\
\hline
\end{tabular}

used in the partially perforated coating pan was always higher than that used in the fully perforated coating pan. This is based on the fact that the partially perforated coating pan features a better use of heat. Thus, it is possible to maintain the tablet temperature while using a higher spray rate, a lower air flow and inlet temperature compared with the fully perforated coating pan.

Comparing the process times of the lots using the same solvent, it is clear that a shorter process time was observed in the partially perforated pan coating due to the higher spray rates used. Consequently, the energy consumption was lower for both solvents studied.

\section{Mean weight and standard deviation of coated tablets and coating process yield}

Table VI shows the mean weight values of the coated tablet, including standard deviation. The standard deviation ranged between 1.7 and 2.2 (Table VI), indicating adequate uniformity within the produced lots.

The statistical analysis of mean weight of the coated tablets showed that the interaction between solvent and the equipment variables ( $p=0.376$ and $0.148, \alpha$-level equal to 0.05 ) were not statistically significant (not shown). The theoretical tablet mean weight after the coating process can be calculated as follows: $250 \mathrm{mg}+3 \%=257.5 \mathrm{mg}$ (Table VII).

The yield rate calculated revealed the real percentage of the tablet weight gain obtained. Thus, we can also calculate the loss of coating dispersion to the hoses and pipes of the spray equipment and, consequently, estimate how much excess dispersion is recommended to make up for these losses in future lots.
Considering the real mean weight of the coated tablets and the theoretical mean weight, excellent process yields were obtained (Table VII). Furthermore, these results indicate that it would not be necessary to prepare excess dispersion to make up for any losses.

The statistical analysis for the yields showed that the solvent and the equipment variables ( $p=0.296$ and 0.201 , $\alpha$-level of 0.05 ) were not significant. Neither the type of solvent nor the type of equipment had a significant impact on the weight of the tablets. This was expected since the data showed that the process time and energy consumption were not a source of variation.

\section{CONCLUSIONS}

The use of statistical tools for quality allowed assessment of the variability in the core production process. This approach assured the cores were not a source of variability in the coating process.

The process employing aqueous solvent and partially perforated pan coater showed a higher efficiency in the coating of cores in terms of process time and energy consumption.

The processes employing partially perforated pan coater and organic solvent, fully perforated pan coater and aqueous solvent and fully perforated pan coater and organic solvent ranked second, third and fourth positions, respectively, regarding efficiency in core coating for process time and energy consumption.

Concerning process yield and final mean weight of the coated tablets, the type of equipment and the solvent used did not cause significant differences in the responses obtained. 
This study contributes to making decisions regarding the purchase of equipment and choice of solvent used in the coating process. Furthermore, the results indicated that, contrary to the beliefs of most technicians, aqueous solvent and a partially perforated drum is the combination that provides the lowest processing time.

\section{REFERENCES}

ALCORN, G.J.; CLOSS, G.H.; TIMKO, R.J.; ROSEMBERG, H.A.; HALL, J.; SHATWELL, J. Comparison of coating efficiency between a Vector Hi-coater and a Manesty Accela-cota. Drug Dev. Ind. Pharm., v.14, n.12, p.1699$1711,1988$.

AVIS, K.E.; SHUKLA, A.J.; CHANG, R.K. Pharmaceutical unit operations: coating. Boca Raton: CRC Press, 1998. $347 \mathrm{p}$.

BAUER, K.H.; LEHMANN, K.; OSTERWALD, H.P.; ROTHGANG, G. Coated pharmaceutical dosage forms. 2.ed. Boca Raton: CRC Press, 1998. 280 p.

CHAN, L.W.; CHAN, W.Y.; HENG, P.W. S. An improved method for the measurement of colour uniformity in pellet coating. Int. J. Pharm., v.213, n.1-2, p.63-74, 2001.

\section{FOOD AND DRUG ADMINISTRATION. FDA. U.S. Guidance} for industry-SUPAC-IR/MR: immediate release and modified release solid oral dosage forms - manufacturing equipment addendum. Available at: <http://www.fda.gov/ Cder/guidance/1721 fnl.pdf $>$. Accessed on: 09 $9^{\text {th }}$ may 2008.

HAN, C.P. Effect of testing normality on estimating process capability indices. Qual. Eng., v.18, n.3, p.391-395, 2006.

HEUVEL, E.R.; ION, R.A. Capability indices and the proportion of nonconforming items. Qual. Eng., v.15, n.3, p.427-439, 2003.

INTERNATIONAL ENERGY INITIATIVE. Available at: $<$ http://www.ieiglobal.org/>. Accessed on: 09 ${ }^{\text {th }}$. may 2008.

LIN, H.; SHEEN, G. Practical implementation of the capability index Cpk based on the control chart data. Qual. Eng., v.17, n.3, p.371-390, 2005.

MCDONALD, R. Colour physics for industry. 2.ed. West Yorkshire: Staples Printers Rochester Ltd., 1997. 111 p.
MONTGOMERY, D.C. Introdução ao controle estatístico da qualidade. 4.ed. Rio de Janeiro: LTC, 2004. 513 p.

MUELLER, R.; KLEINEBUDDE, P. Comparison of a laboratory and a production coating spray gun with respect to scale-up. AAPS PharmSciTech., v.8, n.1, p.E21-31, 2007.

PEARN, W.; LIN, P. Testing process performance based on capability index Cpk with critical values. Comput. Ind. Eng., v.47, n.4, p.351-369, 2004.

PÉREZ-RAMOS, J.D.; FINDLAY, W.P.; PECK, G.; MORRIS, K.R. Quantitative analysis of film coating in a pan coater based on in-line sensor measurements. AAPS Pharm. Sci. Tech., v.6, n.1, p.E127-136, 2005.

PORTER, S.C.; VERSEPUT, R.P.; CUNNINGHAM, C.R. Process optimization using design of experiments. Pharm. Technol., v.21, n.10, p.60-70, 1997.

REGE, B.D.; GAWEL, J.G.; KOU, J.H. Identification of critical process variables for coating actives onto tablets via statistically designed experiments. Int. J. Pharm., v.237, n.1-2, p.87-94, 2002.

SMITH, G.W.; MACLEOD, G.S.; FELL, J.T. Mixing efficiency in side-vented coating equipment. AAPS PharmSciTech., v.4, n.3, p.71-75, 2003.

UNITED STATES PHARMACOPEIA. Rockville: Ed. The United States Pharmacopeal Convention, Inc, 2008. p.266267, 368-369, 675-678.

VISSOTTO, A.L.A.; VILELA, G.L.; CASAIS, E.B.; STEFANI, H.; MARTINELLO, V.; SANTOS JUNIOR, N.; SAMPAIO, M.; BOU-CHACRA, N.A. Abordagem estatística na validação retrospectiva do processo de fabricação de mistura polivitamínica. Rev. Bras. Ciênc. Farm., v.43, n.2, p.263-272, 2007.

VISSOTTO, A.L.A.; WUNDERLER, R.A.; PINTO, T.J.A.; BOU-CHACRA, N.A. Process capability indices determination on tabletting performance during the process validation for metamizol tablets. Pharmind, v.70, n.11, p.1414-1421, 2008.

Received for publication on $11^{\text {th }}$ March 2010. Accepted for publication on $10^{\text {th }}$ June 2010. 